\title{
Global marine plankton functional type biomass distributions: Phaeocystis spp.
}

\author{
M. Vogt ${ }^{1}$, C. O'Brien ${ }^{1}$, J. Peloquin ${ }^{1}$, V. Schoemann ${ }^{2}$, E. Breton ${ }^{3}$, M. Estrada ${ }^{4}$, J. Gibson ${ }^{5}$, D. Karentz ${ }^{6}$, \\ M. A. Van Leeuwe ${ }^{7}$, J. Stefels ${ }^{7}$, C. Widdicombe ${ }^{8}$, and L. Peperzak ${ }^{2}$ \\ ${ }^{1}$ Institute for Biogeochemistry and Pollutant Dynamics, Universitätsstrasse 16, 8092 Zürich, Switzerland \\ ${ }^{2}$ Royal Netherlands Institute for Sea Research, P.O. Box 59, 1790 AB Den Burg (Texel), The Netherlands \\ ${ }^{3}$ Université Lille Nord de France, ULCO, CNRS, LOG UMR8187, 32 Avenue Foch, 62930 Wimereux, France \\ ${ }^{4}$ Institut de Ciències del MAR (CSIC), Passeig Maritim de la Barceloneta, 3749, 08003 Barcelona, Catalunya, \\ Spain \\ ${ }^{5}$ Tasmanian Aquaculture and Fisheries Institute, University of Tasmania, Private Bag 50, Hobart Tasmania \\ 7001, Australia \\ ${ }^{6}$ University of San Francisco, College of Arts and Sciences, 2130 Fulton Street, San Francisco, CA 94117, USA \\ ${ }^{7}$ University of Groningen, Centre for Ecological and Evolutionary Studies, Department of Plant Ecophysiology, \\ P.O. Box 14, 9750AA Haren, The Netherlands \\ ${ }^{8}$ Plymouth Marine Laboratory, Prospect Place, The Hoe, Plymouth PL1 3DH, UK \\ Correspondence to: M. Vogt (meike.vogt@env.ethz.ch)
}

Received: 24 April 2012 - Published in Earth Syst. Sci. Data Discuss.: 16 May 2012

Revised: 14 August 2012 - Accepted: 15 August 2012 - Published: 12 September 2012

\begin{abstract}
The planktonic haptophyte Phaeocystis has been suggested to play a fundamental role in the global biogeochemical cycling of carbon and sulphur, but little is known about its global biomass distribution. We have collected global microscopy data of the genus Phaeocystis and converted abundance data to carbon biomass using species-specific carbon conversion factors. Microscopic counts of single-celled and colonial Phaeocystis were obtained both through the mining of online databases and by accepting direct submissions (both published and unpublished) from Phaeocystis specialists. We recorded abundance data from a total of 1595 depth-resolved stations sampled between 1955-2009. The quality-controlled dataset includes 5057 counts of individual Phaeocystis cells resolved to species level and information regarding life-stages from 3526 samples. $83 \%$ of stations were located in the Northern Hemisphere while $17 \%$ were located in the Southern Hemisphere. Most data were located in the latitude range of $50-70^{\circ} \mathrm{N}$. While the seasonal distribution of Northern Hemisphere data was well-balanced, Southern Hemisphere data was biased towards summer months. Mean species- and form-specific cell diameters were determined from previously published studies. Cell diameters were used to calculate the cellular biovolume of Phaeocystis cells, assuming spherical geometry. Cell biomass was calculated using a carbon conversion factor for prymnesiophytes. For colonies, the number of cells per colony was derived from the colony volume. Cell numbers were then converted to carbon concentrations. An estimation of colonial mucus carbon was included a posteriori, assuming a mean colony size for each species. Carbon content per cell ranged from $9 \mathrm{pg} \mathrm{C}^{-1} \mathrm{ll}^{-1}$ (single-celled Phaeocystis antarctica) to $29 \mathrm{pg} \mathrm{C}$ cell $^{-1}$ (colonial Phaeocystis globosa). Non-zero Phaeocystis cell biomasses (without mucus carbon) range from $2.9 \times 10^{-5}$ to $5.4 \times 10^{3} \mu \mathrm{g} \mathrm{Cl} l^{-1}$, with a mean of $45.7 \mu \mathrm{g} \mathrm{Cl}^{-1}$ and a median of $3.0 \mu \mathrm{g} \mathrm{Cl}^{-1}$. The highest biomasses occur in the Southern Ocean below $70^{\circ} \mathrm{S}$ (up to $783.9 \mu \mathrm{g} \mathrm{C} \mathrm{l}^{-1}$ ) and in the North Atlantic around $50^{\circ} \mathrm{N}$ (up to $5.4 \times 10^{3} \mu \mathrm{g} \mathrm{Cl}^{-1}$ ). The original and gridded data can be downloaded from PANGAEA, doi:10.1594/PANGAEA.779101.
\end{abstract}




\section{Introduction}

Plankton functional types (PFTs; Le Quéré et al., 2005) and marine ecosystem composition are important for the biogeochemical cycling of many abundant elements on Earth, such as carbon, nitrogen, and sulphur (e.g. Weber and Deutsch, 2010). In recent decades, changes have been observed in marine plankton communities (Chavez et al., 2003; Reid et al., 2007; Hatun et al., 2009; Beaugrand and Reid, 2003), and these changes are likely to affect local and global biodiversity, fisheries and biogeochemical cycling. Marine ecosystem models based on PFTs (Dynamic Green Ocean Models; DGOMs) have been developed in order to study the lower trophic levels of marine ecosystems and the potential impact of changes in their structure and distribution (Le Quéré et al., 2005). DGOMs have been applied to a wide range of biological and biogeochemical questions (Aumont and Bopp, 2006; Hashioka and Yamanaka, 2007; Moore and Doney, 2007; Vogt et al., 2010; Weber and Deutsch, 2010). However, the validation of these models has proven difficult due to the scarcity of observational abundance and biomass data for individual PFTs.

The MARine Ecosystem DATa (MAREDAT) initiative is a community effort to provide marine ecosystem modellers with global biomass distributions for the major PFTs currently represented in marine ecosystem models (Buitenhuis et al., 2012; silicifiers, calcifiers, nitrogen fixers, DMSproducers, picophytoplankton, bacteria, microzooplankton, mesozooplankton and macrozooplankton). MAREDAT is part of the MARine Ecosystem Model Intercomparison Project (MAREMIP). All MAREDAT biomass fields are publicly available for use in model evaluation and development, and for other applications in biological oceanography.

The haptophyte Phaeocystis has been suggested to play a fundamental role in the global biogeochemical cycling of carbon and sulphur (Le Quéré et al., 2005). Phaeocystis is a globally distributed genus of marine phytoplankton with a polymorphic life cycle, alternating between flagellated, freeliving cells of 3-9 $\mu \mathrm{m}$ in diameter and colonial stages which form colonies reaching several $\mathrm{mm}-\mathrm{cm}$ (Rousseau et al., 1990; Peperzak et al., 2000; Peperzak and Gäbler-Schwarz, 2012; Chen et al., 2002; Schoemann et al., 2005). Three of the six recognised Phaeocystis species are known to form massive blooms of gelatinous colonies (Medlin and Zingone, 2007), which may contribute significantly to carbon export (Riebesell et al., 1995; DiTullio et al., 2000), although recent observations suggest that the contribution of Phaeocystis spp. to vertical flux of organic matter is small (Reigstad and Wassmann, 2007). In addition, Phaeocystis cells are important producers of dimethylsulphoniopropionate (DMSP), which is the marine precursor of the trace gas dimethylsulphide (DMS). DMS has been suggested to play an important role in cloud formation, and DMS production is the main recycling pathway of sulphur from the ocean to the land. Furthermore, Phaeocystis has been well documented as asso- ciated with marked increases in seawater viscosity (Jenkinson and Biddanda, 1995; Seuront et al., 2007). In their review, Schoemann et al. (2005) conclude that it should be possible to derive a single unique parameterisation of Phaeocystis growth for global modelling. Hence, Phaeocystis has recently been included in a number of regional and global DGOMs (e.g. Wang and Moore, 2011).

Here, we present biomass data that were estimated from direct cell counts of colonial and single-celled Phaeocystis. We show the spatial and temporal distribution of Phaeocystis biomass, with a particular emphasis on the seasonal and vertical patterns. We discuss in detail our method for converting abundance to carbon biomass and note the uncertainties in the carbon conversions. Our biomass estimates are tailored to suit the needs of the modelling community for marine ecosystem model validation and model development, but they are also intended to aid biological oceanographers in the exploration of the relative abundances of different PFTs in the modern ocean and their respective biogeochemical roles, for the study of ecological niches in marine ecosystems and the assessment of marine biodiversity.

\section{Data}

\subsection{Origin of data}

Our data consists of abundance measurements from several databases (BODC, OBIS, OCB DMO, Pangaea, WOD09, US JGOFS ${ }^{1}$ ), and published and unpublished data from several contributing authors (E. Breton, M. Estrada, J. Gibson, D. Karentz, M. A. Van Leeuwe, J. Peloquin, L. Peperzak, V. Schoemann, J. Stefels, C. Widdicombe). Often, the online databases did not denote the method used for the quantitative analysis of Phaeocystis abundances. However, most known counts have been made using the common inverted microscopy and epifluorescence methods (Karlson et al., 2010). Both methods require the sampling of Phaeocystis colonies in Niskin bottles and the subsequent preservation of cells in Lugol's solution or another preservative. After storage of the sample prior to analysis, many scientists concentrate the sample through settling in counting chambers or filtration onto a polycarbonate filter.

Most conventional preservation agents cause the disintegration of the colonial matrix, such that colonial and single cells can no longer be distinguished. One preservation method based on a mixture of Lugol's, glutaraldehyde and iodine (Guiselin et al., 2009; Sherr and Sherr, 1993; Rousseau et al., 1990) is able to maintain colony structure (e.g. Karentz and Spero, 1995; Riebesell et al., 1995; Brown et al., 2008;

\footnotetext{
${ }^{1}$ BODC: British Oceanographic Data Centre; OBIS: The Ocean Biogeographic Information System, OCB DMO: Ocean Carbon and Biogeochemistry Coordination and Data Management Office, Pangaea: Data Publisher for Earth and Environmental Science, WOD: World Ocean Database Boyer et al. (2009), US JGOFS: US Joint Global Ocean Flux Study.
} 
Wassmann et al., 2005), but this is not widely used. Due to these difficulties, only a few measurements resolve Phaeocystis life stages or morphotypes.

Table 1 summarizes the origin of all our data, sorted by database, principal investigator and the project during which measurements were taken. At present, the database contains 5057 individual data points from 3526 samples of 1595 depth-resolved stations.

\subsection{Quality control}

Given the low numbers of data points and the fact that Phaeocystis is a blooming species with a wide range of biomass concentrations, the identification and rejection of outliers in our dataset is challenging. We use Chauvenet's criterion to identify statistical outliers in the log-normalized biomass data (Glover et al., 2011; Buitenhuis et al., 2012). Based on the analysis, none of the stations was identified to yield biomasses with a probability of deviation from the mean greater than $1 / 2 n$, with $n=2547$ being the number of non-zero data summed up for all stations (two-sided $\mathrm{z}$ score: $|z c|=3.72$ ). In addition to the statistical testing of the biomass distribution, we also quality controlled the range of our cell abundances. We found that our maximum reported

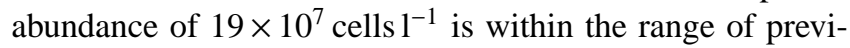
ously reported abundances: Schoemann et al. (2005) report maximum cell abundances of the order of ca. $10^{7}$ cells $1^{-1}$ in areas of colony occurrence (http://www.nioz.nl/projects/ ironages). The largest bloom of $P$. antarctica was observed in Prydz Bay (http://www.nioz.nl/projects/ironages), with cell abundances measured up to $6 \times 10^{7}$ cells $^{-1}$. Eilertsen et al. (1989) reported a maximum of $1.2 \times 10^{7}$ cells $^{-1}$ of $P$. pouchetii in the Konsfjord. For $P$. globosa, a maximal abundance of $20 \times 10^{7}$ cells $1^{-1}$ has been observed, corresponding to a total biomass of ca. $10 \mathrm{mg} \mathrm{Cl}^{-1}$ including mucus (Cadée and Hegeman, 1986; Schoemann et al., 2005). The latter biomass value is 20 times larger than the maximal biomass we report $\left(5.4 \times 10^{3} \mu \mathrm{gCl}^{-1}\right)$. Thus, based on statistical and observational evidence, none of the data were flagged.

\subsection{Biomass conversion}

We distinguish between single, colonial and unspecified Phaeocystis cells. While Phaeocystis is generally observed and counted under bloom conditions, a significant fraction of cells is non-colonial even during bloom conditions (V. Schoemann, auxillary data). Hence, in order to calculate the lower limit biomass, we have assumed unspecified cells to be single cells. To first order, this choice does not affect the order of magnitude of our cell biomass estimates, since cell carbon is of the same order of magnitude for both colonial and single cells (see below). We define total Phaeocystis biomass to consist of cell biomass and biomass contained in the mucus surrounding Phaeocystis colonies. For our calculation of total biomass, we chose unidentified cells to be in the colonial stage. Hence, our cell biomass estimates represent a lower limit, and our total biomass estimates including colonial mucus represent an upper limit for global Phaeocystis biomass.

Biomass was determined from cell abundance using species- and form-specific conversion factors (Fig. 1). Similar conversion schemes have been previously described (e.g. Schoemann et al., 2005, and references therein). Total cell abundances were divided into single cells, colonial cells and undefined cell types. For each species, the mid-point of the range of reported cell diameters from the literature was used for single and colonial cells (Table 2; P. globosa: Rousseau et al., 2007; Schoemann et al., 2005; $P$. antarctica: Mathot et al., 2000; Rousseau et al., 2007; Schoemann et al., 2005; P. pouchetii: Wassmann et al., 2005; Rousseau et al., 2007).

Where the species was not specified, Southern Ocean cell counts were assumed to be Phaeocystis antarctica. For cell counts in other regions, the mid-point of the range of cell diameters for P. pouchetii and P. globosa was taken (Table 2; flagellates: $5.0 \mu \mathrm{m}$, colonial cells: $6.7 \mu \mathrm{m}$ ). From cell diameter we computed biovolume, assuming spherical geometry of all cell types. We then converted biovolume to carbon biomass using an empirical volume-carbon conversion formula for prymnesiophytes developed by Menden-Deuer and Lessard (2000, Table 2).

Most colonial cells were reported in the form of cell abundances. However, one dataset (P. globosa; number of data points: $n=30$ ) provided colony counts only, but additionally reported the corresponding colony diameters. We used the reported colony diameter to calculate colony volume (assuming spherical colonies), and from this estimated the number of cells per colony using published conversion factors (Table 2; P. globosa: Rousseau et al., 1990; P. antarctica: Mathot et al., 2000; no colony-only cell counts reported for $P$. pouchetii). Total cell counts per colony were then converted to carbon biomass using the method described above.

We show biomass estimates based on cell carbon excluding colonial mucus as our lower limit for Phaeocystis biomass. The range of uncertainty for the lower limit biomass estimates is given by the uncertainty in cell diameters. Additional uncertainty is introduced where cell life form is not specified. The uncertainty introduced by this assumption is addressed by calculating a minimum cell biomass estimate treating all undefined cell types as single cells.

Estimates for colonial mucus are included to provide an upper limit for Phaeocystis biomass. Estimating mucus carbon from cell counts alone is problematic, as the ratio of mucus carbon to cell number increases with colony size. Colony size therefore needs to be known in order to calculate accurate estimates of mucus carbon. Only one of the datasets $(n=30)$ included information on colony size. Consequentially, we have used a standard colony diameter of $200 \mu \mathrm{m}$ for all three species, based on a review of previously reported colony sizes: Verity et al. (2007) find most $P$. pouchetii colonies in their study range between $20-450 \mu \mathrm{m}$ 
Table 1. List of data contributors, in temporal order; Databases: BODC: British Oceanographic Data Centre, OBIS: Ocean Biogeographic Information System, US JGOFS: US Joint Global Ocean Flux Study, OCB: Ocean Carbon and Biogeochemistry, WOD09: World Ocean Database 2009; Institutes: AWI: Alfred-Wegener-Institute, Bremerhaven, Germany, IMARPE: Institut del Mar del Peru, Paita, Peru, IOS: Institute of Ocean Sciences, Sidney, Canada, MMBI: Murmansk Marine Biological Institute, Murmansk, Russia.

\begin{tabular}{|c|c|c|c|c|c|c|c|}
\hline $\begin{array}{l}\text { Entry } \\
\text { No. }\end{array}$ & Database & Investigator/Institute & Project & Year(s) & Region & $\begin{array}{l}\text { No. of data } \\
\text { points }\end{array}$ & Reference(s) \\
\hline 1 & BODC & D. Harbour & BOFS & 1989-1991 & North Atlantic & 13 & - \\
\hline 2 & BODC & D. Harbour & JGOFS & 1994 & Arabian Sea & 25 & - \\
\hline 3 & BODC & I. Joint & OMEX & 1994-1995 & North Atlantic & 7 & - \\
\hline 4 & BODC & P. Tett & $\begin{array}{l}\text { North Sea } \\
\text { Project }\end{array}$ & 1988-1989 & North Sea & 18 & - \\
\hline 5 & BODC & R. Uncles & LOIS & 1994-1995 & North Sea & 19 & - \\
\hline 6 & BODC & P. Wassmann & OMEX & 1994 & North Atlantic & 186 & - \\
\hline 7 & - & L. Peperzak & & 1992 & Dutch coastal zone & 64 & Peperzak et al. (1998) \\
\hline 8 & OBIS & $\begin{array}{l}\text { P. Wassmann \& T. } \\
\text { Ratkova }\end{array}$ & ArcOD & 1993-2003 & Arctic & 1815 & - \\
\hline 9 & OCB DMO & M. Silver & VERTIGO & 2004 & Hawaii & 1 & \\
\hline 10 & Pangaea & P. Assmy & EIFEX & 2004 & Southern Ocean & 28 & Assmy (2007) \\
\hline 11 & Schoemann et al. (2005) & G. Cadée & Marsdiep & $1976-1985$ & Dutch coastal zone & 2 & Cadée and Hegeman (1986) \\
\hline 12 & Schoemann et al. (2005) & G. Cadée & Marsdiep & 1989-1992 & Dutch coastal zone & 3 & Cadée (1991) \\
\hline 13 & Schoemann et al. (2005) & G. Cadée & Marsdiep & 1990 & Dutch coastal zone & 2 & Cadée (1991) \\
\hline 14 & Schoemann et al. (2005) & G. DiTullio & & 1996 & Ross Sea, Antarctica & 1 & DiTullio et al. (2000) \\
\hline 15 & Schoemann et al. (2005) & $\begin{array}{l}\text { H. Fransz \& } \\
\text { G. Cadée }\end{array}$ & Marsdiep & 1991 & Dutch coastal zone & 2 & Fransz et al. (1992) \\
\hline & & & & & & & Cadée and Hegeman (1993) \\
\hline 16 & Schoemann et al. (2005) & B. Hansen & & 1988-1989 & Barents Sea & 6 & Hansen et al. (1990) \\
\hline 17 & Schoemann et al. (2005) & I. Jenkinson & & 1988 & German Bight & 12 & Jenkinson and Biddanda (1995) \\
\hline 18 & Schoemann et al. (2005) & S. Kang & & 1986 & $\begin{array}{l}\text { Weddell Sea, } \\
\text { Antarctica }\end{array}$ & 3 & Kang and Fryxell (1993) \\
\hline 19 & Schoemann et al. (2005) & B. Karlson & & 1993 & $\begin{array}{l}\text { Skagerrak Strait, } \\
\text { North Sea }\end{array}$ & 5 & Karlson et al. (1996) \\
\hline 20 & Schoemann et al. (2005) & K. Kennington & & 1996 & Irish Sea & 1 & Kennington et al. (1999) \\
\hline 21 & Schoemann et al. (2005) & A. Luchetta & & 1991 & Barents Sea & 1 & Luchetta et al. (2000) \\
\hline 22 & Schoemann et al. (2005) & S. Mathot & & 1994-1995 & Ross Sea, Antarctica & 35 & Mathot et al. (2000) \\
\hline 23 & Schoemann et al. (2005) & Palmisano & & 1984 & $\begin{array}{l}\text { McMurdo Sound, } \\
\text { Antarctica }\end{array}$ & 10 & Palmisano et al. (1986) \\
\hline 24 & Schoemann et al. (2005) & H. Pieters & Marsdiep & 1978 & Dutch coastal zone & 1 & Pieters et al. (1980) \\
\hline 25 & Schoemann et al. (2005) & R. Riegman & Marsdiep & 1991 & Dutch coastal zone & 4 & Riegman et al. (1993) \\
\hline 26 & Schoemann et al. (2005) & C. Robinson & & 1993 & East Antarctica & 1 & Robinson et al. (1999) \\
\hline 27 & Schoemann et al. (2005) & F. Scott & & 1992 & East Antarctica & 1 & Scott et al. (2000) \\
\hline 28 & Schoemann et al. (2005) & P. Tréguer & & 1988 & Scotia Sea, Antarctica & 1 & Tréguer et al. (1991) \\
\hline 29 & Schoemann et al. (2005) & F. Van Duyl & Marsdiep & 1995 & Dutch coastal zone & 2 & Van Duyl et al. (1998) \\
\hline 30 & Schoemann et al. (2005) & E. Venrick & - & 1994 & REGION & 1 & Venrick (1997) \\
\hline 31 & Schoemann et al. (2005) & S. Weaver & - & 1994 & REGION & 1 & Weaver (1979) \\
\hline 32 & Schoemann et al. (2005) & T. Weisse & & 1975-1976 & $\begin{array}{l}\text { German Bight, } \\
\text { North Sea }\end{array}$ & 2 & Weisse et al. (1986) \\
\hline 33 & Schoemann et al. (2005) & G. Wolfe & & 1997 & Labrador Sea & 2 & Wolfe et al. (2000) \\
\hline 34 & WOD09 & MMBI & - & $1955-1997$ & $\begin{array}{l}\text { Kola Bay } \\
\text { (Barents Sea) }\end{array}$ & 395 & - \\
\hline 35 & WOD09 & IMARPE & - & $1966-1977$ & Peruvian coastal zone & 8 & - \\
\hline 36 & WOD09 & IOS & - & 1980 & US coast (Oregon) & 4 & - \\
\hline 37 & WOD09 & $\begin{array}{l}\text { University of } \\
\text { Alaska }\end{array}$ & OCSEAP & $1975-1977$ & $\begin{array}{l}\text { Prince William Sound } \\
\text { (Gulf of Alaska) }\end{array}$ & 20 & - \\
\hline 38 & WOD09 & AWI & IAPP & 1991 & Arctic & 6 & \\
\hline 39 & - & C. Widdicombe & $\begin{array}{l}\text { Western Chan- } \\
\text { nel Observatory }\end{array}$ & 1992-2008 & English Channel & 1248 & Widdicombe et al. (2010) \\
\hline 40 & US JGOFS Data System & $\begin{array}{l}\text { W. Smith, } \\
\text { D. Caron \& } \\
\text { D. Lonsdale }\end{array}$ & AESOPS & 1996-1997 & Southern Ocean & 184 & - \\
\hline 41 & - & D. Karentz & Icecolors & 1986 & Southern Ocean & 74 & $\begin{array}{l}\text { Karentz and Spero (1995); } \\
\text { Smith et al. (1992) }\end{array}$ \\
\hline 42 & - & D. Karentz & GRINCHES & 2004-2005 & Ross Sea, Antarctica & 14 & \\
\hline 43 & - & E. Breton & $\begin{array}{l}\text { SOMLIT- } \\
\text { MONITO }\end{array}$ & 2006-2009 & English Channel & 216 & E. Breton (unpublished data) \\
\hline 44 & - & J. Gibson & & 1993-1995 & East Antarctica & 136 & J. Gibson (unpublished data) \\
\hline 45 & - & J. Peloquin & Ross Sea & 2001-2005 & Ross Sea, Antarctica & 84 & J. Peloquin (unpublished data) \\
\hline 46 & - & $\begin{array}{l}\text { M. Van Leeuwe \& } \\
\text { J. Stefels }\end{array}$ & $\begin{array}{l}\text { Ant } 16 / 3 \\
\text { R/V Polarstern }\end{array}$ & 1999 & Southern Ocean & 33 & Koeman (1999) \\
\hline 47 & - & M. Estrada & Antarctic 85 & 1985 & $\begin{array}{l}\text { Weddell Sea, } \\
\text { Antarctica }\end{array}$ & 126 & Estrada and Delgado (1990) \\
\hline 48 & - & M. Estrada & Fronts & 1985 & Mediterranean Sea & 156 & Estrada (1991) \\
\hline 49 & - & V. Schoemann & $\begin{array}{l}\text { BGC of Phaeo- } \\
\text { cystis colonies, } \\
\text { EC-FP4 }\end{array}$ & 1994 & Dutch coastal zone & 80 & Schoemann et al. (1998) \\
\hline
\end{tabular}




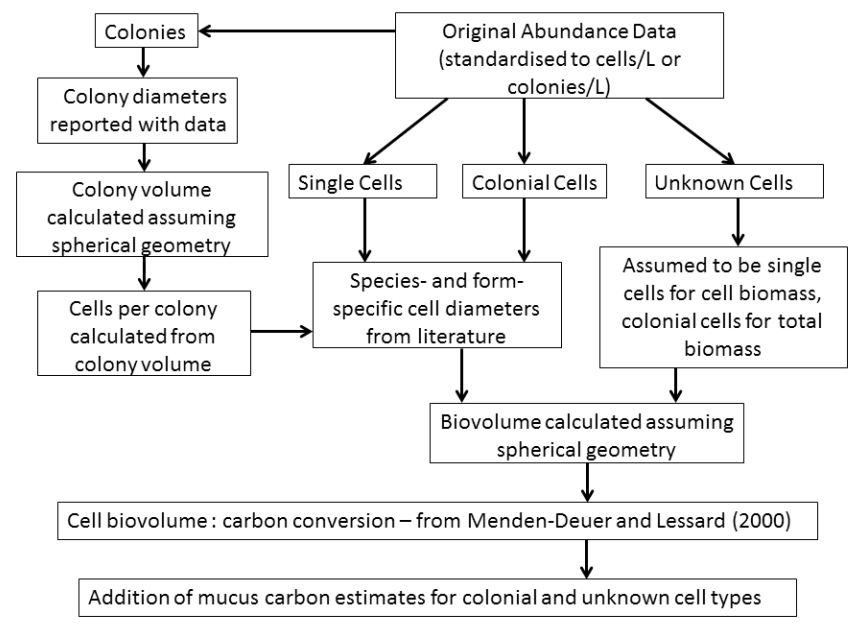

Figure 1. Flow diagram of methodology used to derive mean Phaeocystis biomass estimates from abundance data for single cells, colonial cells and unidentified cells. Abundance data was converted to biovolume, and a biovolume to carbon ratio was applied to derive biomass. Finally, an estimate of mucus carbon was added for colonial cell types.

in diameter; Reigstad and Wassmann (2007) observe most of their $P$. pouchetii colonies in a size range between 65$115 \mu \mathrm{m}$; Mathot et al. (2000) observe $P$. antarctica colonies to range from 9.3-560 $\mu \mathrm{m}$; and Rousseau et al. (1990) report colony sizes of $P$. globosa to range from $10 \mu \mathrm{m}-2 \mathrm{~mm}$. In all references, larger colonies occured, but were rarer than the smaller colonies. In our data, $P$. globosa colonies range from $11-594 \mu \mathrm{m}$ in diameter, with a mean diameter of $197 \mu \mathrm{m}$. Given that the samples of Verity et al. (2007), Mathot et al. (2000) and Rousseau et al. (1990) cover a similar range of sizes for all three species, and that the dataset that reports colony sizes confirms a mean colony size of ca. $200 \mu \mathrm{m}$, these findings suggest that the chosen standard diameter is a realistic value for a typical Phaeocystis bloom. Maximum sizes are reported in Schoemann et al. (2005) and Baumann et al. (1994), and range between $9 \mathrm{~mm}-3 \mathrm{~cm}$ for $P$. globosa, between $1.5-2 \mathrm{~mm}$ for $P$. pouchetii, and around $1.4-9 \mathrm{~mm}$ for $P$. antarctica. Given the lack of data on colony sizes, we are unable to quantify the impact of large colonies on average carbon biomass. However, huge colony sizes are likely to be geographically restricted to specific regions. We assess the uncertainty of our estimates by calculating mucus carbon for the minimum and maximum colony sizes reported for each species (Schoemann et al., 2005; Baumann et al., 1994). Estimates of minimal and maximal total carbon are included in our data base, but only mean total carbon including mucus will be discussed below.

Conversion factors have previously been published for estimating mucus biomass and number of cells from colony volume for P. antarctica (Mathot et al., 2000) and P. globosa (Rousseau et al., 1990). Using these estimates we calculated

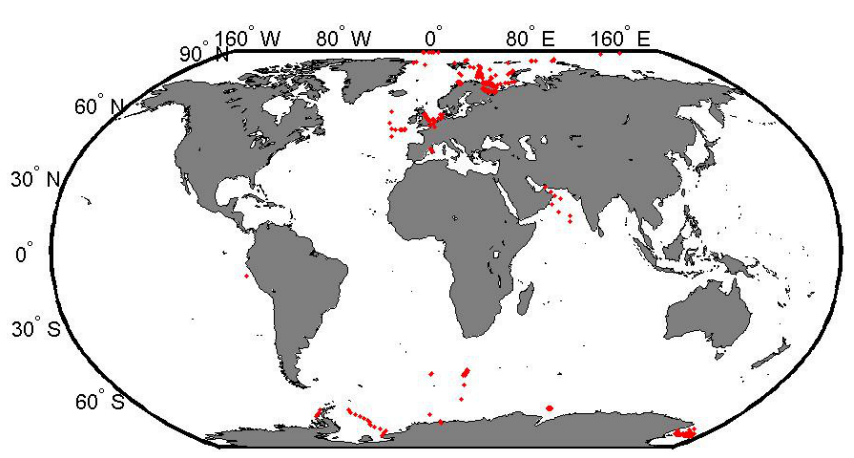

Figure 2. Global distribution of stations where Phaeocystis abundance counts were made available for this study. Most stations are located at temperate latitudes and in coastal areas.

the expected mucus biomass per cell (Table 2). Unspecified cell types were assumed to be colonial cells when calculating these upper estimates of Phaeocystis biomass.

For $P$. pouchetii, no direct mucus carbon conversion factor has been developed, but Verity et al. (2007) provides a conversion factor for colony volume to total colony biomass (Table 2; cells and mucus). Following the same procedure as for the other two species, we used this to calculate total biomass per cell. We then subtracted our cell biomass estimate for colonial cells to obtain an estimate of mucus carbon per cell for comparison with $P$. globosa and $P$. antarctica estimates.

Unspecified species outside of the Southern Ocean were given a total biomass per cell of $224 \mathrm{pg}$, which corresponds to the mean total biomass estimate for $P$. globosa and $P$. pouchetii (Table 2).

\section{Results}

\subsection{Global distribution of abundance data}

Of the 1595 stations contained in the database (Fig. 2), $83 \%$ are located in the Northern Hemisphere (NH) and only $17 \%$ in the Southern Hemisphere (SH; Fig. 3). Out of the 3526 samples, 2547 were reported as non-zero biomass, with 2054 non-zero abundances out of 2862 samples for the $\mathrm{NH}$, and 493 non-zero abundances out of 664 samples for the SH (Table 3). Most measurements (53\%) were taken in the latitudinal band of $50-70^{\circ} \mathrm{N}$ (Fig. 3). When only data points with non-zero abundances are taken into account, we find that most non-zero data were collected between $60-80^{\circ} \mathrm{N}(64 \%$; Table 3), with relatively few non-zero abundances recorded between $50-60^{\circ} \mathrm{N}(11 \%)$. Several latitudinal bands are undersampled. We could not collect data for the $40-20^{\circ} \mathrm{S}, 0$ $10^{\circ} \mathrm{N}$ and $30-40^{\circ} \mathrm{N}$ latitudinal bands. All in all, we have little non-zero data in tropical and sub-tropical latitudes from $40^{\circ} \mathrm{S}$ to $40^{\circ} \mathrm{N}$, where sampling is targeted at other phytoplankton groups. 
Table 2. Literature values for conversion factors from abundance to biomass. Cell diameters, biovolumes, carbon content and colony number conversions for $P$. globosa, P. pouchetii, and P. antarctica. Reported means with ranges given in parentheses.

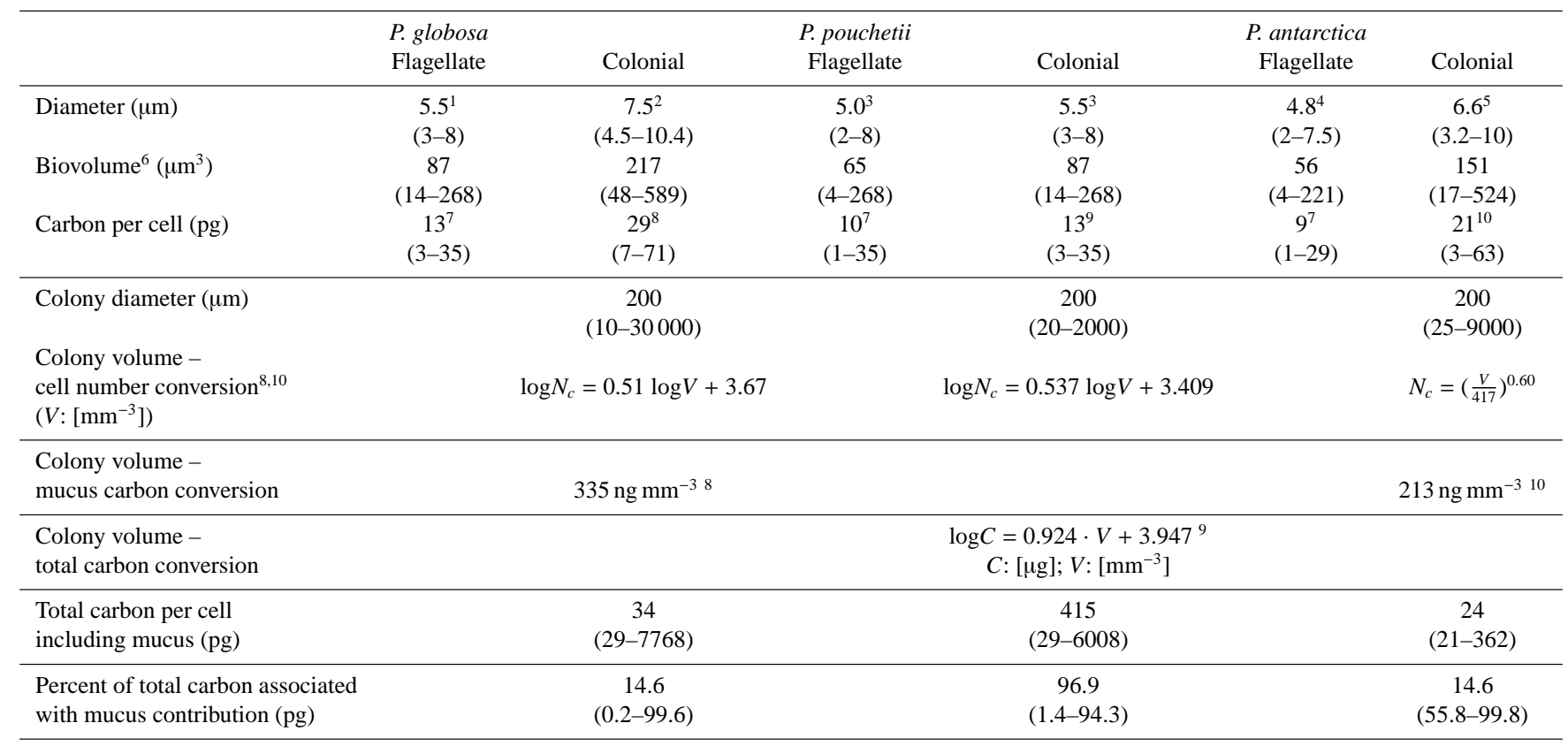

References for the cell diameters: ${ }^{1}$ Rousseau et al. (2007); Schoemann et al. (2005); ${ }^{2}$ Rousseau et al. (2007); ${ }^{3}$ Wassmann et al. (2005); Rousseau et al. (2007); ${ }^{4}$ Schoemann et al. (2005); Mathot et al. (2000); Rousseau et al. (2007); ${ }^{5}$ Mathot et al. (2000); Rousseau et al. (2007). References for biovolume conversion, assuming spherical geometry of cells:

${ }^{6}$ Hillebrand et al. (1999). Reference for the biovolume-carbon conversion: ${ }^{7}$ Menden-Deuer and Lessard (2000). References for colony volume-cell number conversion and for colony volume-mucus biomass conversion: ${ }^{8}$ Rousseau et al. (1990); ${ }^{9}$ Verity et al. (2007) (colony volume-total biomass conversion); ${ }^{10}$ Mathot et al. (2000).

While $60 \%$ of measurements were taken in the upper $10 \mathrm{~m}$ of the water column, the mean sampling depth of our dataset is $27 \mathrm{~m}$, and the median sampling depth is $10 \mathrm{~m}$. Reported cell abundances were maximal at depths between 0 $80 \mathrm{~m}$. Observations and laboratory experiments suggest that Phaeocystis is well-adapted to low light conditions (Arrigo et al., 1999; Moore et al., 2007; Shields and Smith, 2009). In our database, the deepest occurrence of Phaeocystis was at $292 \mathrm{~m}$ at $65^{\circ} \mathrm{N}, 35^{\circ} \mathrm{W}$ (Barents Sea; OBIS dataset).

\subsection{Temporal distribution of data}

The data were collected from 1955-2009, with $79 \%$ of measurements taken during the period of 1990-2009 (Fig. 4). 6\% $(8 \%)$ of (non-zero) measurements were taken in the 1950s, $<1 \%(<1 \%)$ in the 1960 s, $<1 \%(1 \%)$ in the 1970 s, $14 \%$ $(10 \%)$ in the $1980 \mathrm{~s}, 55 \%(60 \%)$ in the $1990 \mathrm{~s}$, and $23 \%$ (20\%) between 2000-2009.

Dividing the data into the four seasons for both hemispheres gives a first indication of the level of temporal bias (Table 4). In the Northern Hemisphere, $56 \%$ (64\%) of all (non-zero) data were taken in spring, $29 \%(31 \%)$ in summer, $9 \%(5 \%)$ in autumn and $6 \%(<1 \%)$ in winter. For the Southern Hemisphere, $27 \%$ (32\%) of data were collected in spring, $58 \%(52 \%)$ in summer, $13 \%(16 \%)$ in autumn and only $2 \%(<1 \%)$ in winter. Hence, NH data is biased towards spring values, and $\mathrm{SH}$ data towards summer values.

\subsection{Phaeocystis cell biomass distribution (mucus excluded)}

Phaeocystis biomass estimates based on cell carbon only, without mucus carbon included, constitute a lower boundary for carbon biomass of this PFT in the global ocean. Since mucus carbon biomass is difficult to quantify based on Phaeocystis cell counts, many marine ecosystem models do not include a parameterisation of mucus carbon for this PFT. Thus, in the following section, our estimates of cell biomass represent a lower limit of carbon biomass for model validation. Phaeocystis biomasses span a wide range of concentrations, which is why we show log transformed biomass concentrations in all subsequent figures. However, we report only non log-transformed biomass concentrations in this manuscript for better comparability with the original data submission.

\subsubsection{Global surface cell biomass characteristics}

Phaeocystis biomass estimated from cell carbon alone is depicted in Fig. 5a for the surface layer of the ocean (0$5 \mathrm{~m})$. The maximal biomass calculated from the reported cell abundances is $5449.3 \mu \mathrm{g} \mathrm{Cl}^{-1}$, located at $53^{\circ} \mathrm{N}$ at a depth of $0 \mathrm{~m}$ during the spring bloom (month of May). The maximal cell biomass in the Southern Hemisphere is $783.9 \mu \mathrm{g} \mathrm{Cl}^{-1}$, recorded in the Ross Sea in January $\left(76.49^{\circ} \mathrm{S}, 171.97^{\circ} \mathrm{E}\right.$, depth $1 \mathrm{~m}$ ). The mean of all reported non-zero cell biomass values is $45.7 \mu \mathrm{g} \mathrm{Cl}^{-1}$, and the median is $3.0 \mu \mathrm{g} \mathrm{Cl}^{-1}$. Of 


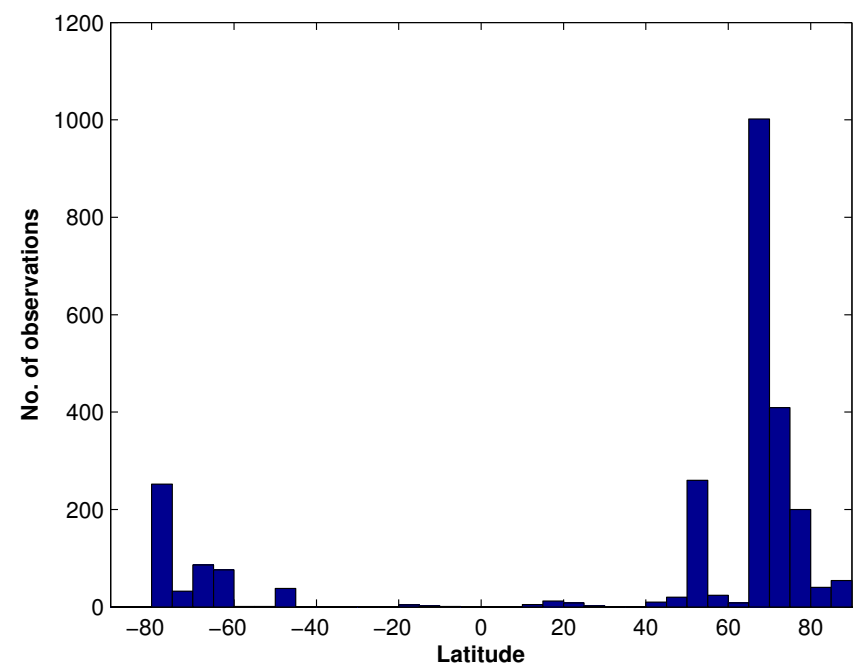

Figure 3. Number of Phaeocystis observations as a function of latitude for the period of 1950-2009. Most observations are located in the temperate and high latitudes of the Northern Hemisphere.

all calculated cell biomasses, $40.1 \%$ are in the range of 0 $0.1 \mu \mathrm{g} \mathrm{Cl} 1^{-1}, 55.6 \%$ in the range of $0-1 \mu \mathrm{g} \mathrm{Cl}^{-1}$, and $67.5 \%$ between 0 and $5 \mu \mathrm{g} \mathrm{Cl}^{-1}$. $94.8 \%$ of all cell biomasses lie below $100 \mu \mathrm{g} \mathrm{Cl} 1^{-1}$.

Figure $5 \mathrm{~b}$ shows the range of uncertainty for cell biomass in $\%$ resulting from the uncertainty in cell diameters reported for each species and life stage. Biomasses calculated using the higher estimates of cell diameter are 246 to $355 \%$ higher than estimates calculated using mean cell dimensions. Biomasses calculated using the lower cell diameter estimates are between 4 and $26 \%$ of the mean values. Uncertainties are highest when species or life form is not reported. Biomass estimates are highly sensitive to changes in cell size, and reduced uncertainty is only possible if cell measurements are available in addition to abundance data.

\subsubsection{Latitudinal cell biomass distribution}

Calculated cell biomasses do not follow a distinct latitudinal pattern (Fig. 6a). Highest cell biomasses occur at latitudes around $50^{\circ} \mathrm{N}$ and $80^{\circ} \mathrm{S}$, lowest cell biomasses are calculated for latitudes around $20^{\circ} \mathrm{S}$ (Peruvian upwelling). Cell biomasses decrease from $50^{\circ} \mathrm{N}$ towards the pole in the Northern Hemisphere, but Southern Hemisphere concentrations increase polewards towards the Antarctic continent. Given that many of our data stem from coastal regions, we note that our latitudinal distributions are biased towards high coastal concentrations in some areas, as open ocean areas are still undersampled. However, cell biomass distributions confirm previous findings that Phaeocystis blooms occur in the temperate and high latitudes of both hemispheres, and that Phaeocystis is fairly ubiquitous, occurring in all major ocean basins.
Table 3. Latitudinal distribution of abundance data in ten degree latitudinal bands $\left(-90\right.$ to $\left.90^{\circ}\right)$. Number of data points for each latitudinal band. All: all measurements, non-zero: data with non-zero carbon biomass.

\begin{tabular}{rcc}
\hline Latitudinal band & All data & Non-zero data \\
\hline$-90--80^{\circ}$ & 0 & 0 \\
$-80--70^{\circ}$ & 334 & 284 \\
$-70--60^{\circ}$ & 283 & 162 \\
$-60--50^{\circ}$ & 1 & 1 \\
$-50--40^{\circ}$ & 37 & 37 \\
$-40--30^{\circ}$ & 0 & 0 \\
$-30--20^{\circ}$ & 0 & 0 \\
$-20--10^{\circ}$ & 6 & 6 \\
$-10-0^{\circ}$ & 1 & 1 \\
$0-10^{\circ}$ & 0 & 0 \\
$10-20^{\circ}$ & 17 & 17 \\
$20-30^{\circ}$ & 10 & 10 \\
$30-40^{\circ}$ & 0 & 0 \\
$40-50^{\circ}$ & 152 & 30 \\
$50-60^{\circ}$ & 852 & 284 \\
$60-70^{\circ}$ & 1010 & 1010 \\
$70-80^{\circ}$ & 727 & 609 \\
$80-90^{\circ}$ & 94 & 94 \\
\hline
\end{tabular}

\subsubsection{Depth distribution of cell biomass}

Figure 7 shows calculated cell biomass estimates for Phaeocystis in six different depth ranges $(0-5 \mathrm{~m}, 5-25 \mathrm{~m}, 25-50 \mathrm{~m}$, 50-75 m, 75-100 $\mathrm{m}$ and depths $>100 \mathrm{~m}$ ). All depth bands have not been sampled at each station, and many datasets contain only surface measurements. Where depth profiles are available, cell biomass concentrations are generally highest in the surface layer and decrease with depth to $100 \mathrm{~m}$ (Fig. 6b). Cell biomasses are low between 100-300 m (mean non-zero biomass concentrations of $7.3 \mu \mathrm{g} \mathrm{Cl}^{-1}$ ), however, high Phaeocystis abundances are reported even at depths of close to $300 \mathrm{~m}$ in the Northern Hemisphere. The highest cell biomass reported below $100 \mathrm{~m}$ is $311.9 \mu \mathrm{g} \mathrm{Cl} l^{-1}$ in the Arctic $\left(66.42^{\circ} \mathrm{N}, 34.36^{\circ} \mathrm{E}\right)$ in late May, at a depth of $270 \mathrm{~m}$. In the Southern Ocean, Phaeocystis cells are reported to a maximum depth of $200 \mathrm{~m}$ in the Weddell Sea during February and March, but biomass values below $100 \mathrm{~m}$ never exceed $0.01 \mu \mathrm{g} \mathrm{Cl}^{-1}$. Given the limited number of data points reported for this depth range, it is unclear how representative our data are of deep Phaeocystis cell biomasses in other sampling locations. This suggests that Phaeocystis should be sampled more regularly at depths between $100-300 \mathrm{~m}$ and below.

\subsubsection{Seasonal distribution of cell biomass}

Cell biomass distributions for the Northern and Southern Hemispheres show that the calculated Phaeocystis biomasses reflect those of a typical blooming species (Fig. 8a and b). In 


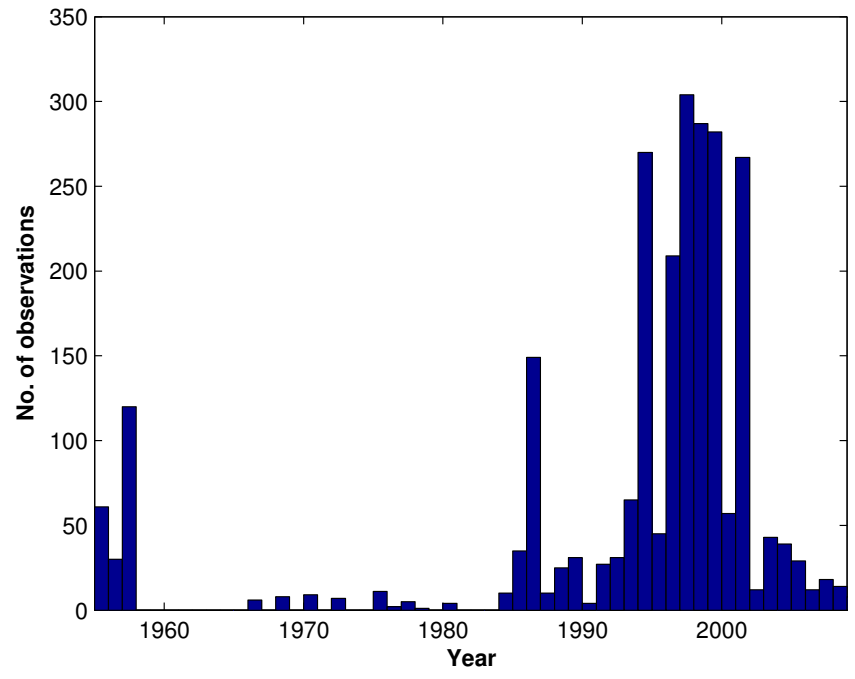

Figure 4. Number of observations for Phaeocystis species per year, for the years 1950-2009. Most counts were made after 1990.

the NH, Phaeocystis blooms during the spring months, with the spread of the biomass distribution being a combination of the temporal development of a bloom, and different bloom starting times at different latitudes. In the $\mathrm{SH}$, cell biomasses are highest in December and January. The temporal development mostly reflects Southern Ocean dynamics, as few samples were taken at latitudes below $40^{\circ} \mathrm{S}$ (compare Fig. $6 \mathrm{~b}$ ).

\subsection{Total Phaeocystis biomass distribution (mucus included)}

Biomass estimates including colonial mucus are given as an upper limit for our biomass estimates (Fig. 9a). Given that the ratio of mucus carbon to cell carbon is highly dependent on colony size, the addition of mucus carbon estimates introduces a high level of uncertainty to total biomass estimates where colony size data is unavailable. Calculating mucus carbon biomass based on the minimum and maximum reported colony sizes for each species (Schoemann et al., 2005) gives a huge range of values: percent colony carbon as mucus ranges from $0.2-99.6 \%$ for $P$. globosa, $1.4-94.3 \%$ for $P$. antarctica and 55.8-99.8\% for $P$. pouchetii. Using a standard colony diameter of $200 \mu \mathrm{m}$ increases biomass estimates by a factor of 1.2 for colonial $P$. globosa and $P$. antarctica cells, but by 32.8 for $P$. pouchetii compared to estimates considering cell biomass alone. The contribution of (standard) mucus to total carbon per cell is $96.9 \%$ for $P$. globosa, and $14.6 \%$ for P. pouchetii and P. antarctica (Table 2) for this standard colony size. The difference between the three species leads to a larger contribution by the Northern Hemisphere species to total Phaeocystis biomass (Fig. 9a and b).

Total Phaeocystis biomass estimates including (standard) mucus range from $2.9 \times 10^{-5} \mu \mathrm{g} \mathrm{Cl}^{-1}$ to $19823 \mu \mathrm{g} \mathrm{Cl}^{-1}$. The maximal total biomass $\left(19823 \mu \mathrm{g} \mathrm{Cl}^{-1}\right)$ is 3.6 times higher
Table 4. Seasonal distribution of abundance data for the Northern and Southern Hemispheres. Number of data points for each month. All: all data, non-zero: data with non-zero carbon biomass. 27 observations did not include the month when measurements were taken.

\begin{tabular}{lcccccc}
\hline Month & $\begin{array}{c}\text { Globe } \\
\text { all }\end{array}$ & $\begin{array}{c}\text { Globe } \\
\text { non-zero }\end{array}$ & $\begin{array}{c}\text { NH } \\
\text { all }\end{array}$ & $\begin{array}{c}\text { NH } \\
\text { non-zero }\end{array}$ & $\begin{array}{c}\text { SH } \\
\text { all }\end{array}$ & $\begin{array}{c}\text { SH } \\
\text { non-zero }\end{array}$ \\
\hline January & 164 & 82 & 59 & 4 & 105 & 78 \\
February & 213 & 56 & 59 & 4 & 154 & 52 \\
March & 379 & 187 & 347 & 157 & 32 & 30 \\
April & 687 & 641 & 638 & 593 & 49 & 48 \\
May & 618 & 561 & 612 & 560 & 6 & 1 \\
June & 384 & 318 & 380 & 318 & 4 & 0 \\
July & 263 & 185 & 258 & 183 & 5 & 2 \\
August & 202 & 131 & 198 & 131 & 4 & 0 \\
September & 119 & 56 & 114 & 56 & 5 & 0 \\
October & 169 & 94 & 90 & 27 & 79 & 67 \\
November & 164 & 94 & 67 & 15 & 97 & 91 \\
December & 164 & 130 & 40 & 6 & 124 & 124 \\
\hline Spring & - & - & 1597 & 1310 & 181 & 158 \\
Summer & - & - & 836 & 632 & 383 & 254 \\
Autumn & - & - & 271 & 98 & 87 & 79 \\
Winter & - & - & 158 & 14 & 13 & 2 \\
\hline Total & 3526 & 2547 & 2862 & 2054 & 664 & 493 \\
\hline
\end{tabular}

than the corresponding data point with the maximal cell biomass of $5449.3 \mu \mathrm{g} \mathrm{Cl}{ }^{-1}$. This data point is associated with high cell numbers during a bloom of $P$. pouchetii off the coast of the Netherlands in the Wadden Sea. In contrast, the maximal total biomass in the Southern Hemisphere is only $918 \mu \mathrm{g} \mathrm{Cl}^{-1}$, and thus one order of magnitude lower than maximal total biomasses in the Northern Hemisphere (Fig. 9). The global mean of all reported nonzero total biomass values is $183.8 \mu \mathrm{g} \mathrm{Cl}^{-1}$, and the median is $11.3 \mu \mathrm{g} \mathrm{Cl}^{-1}$. While our publicly available dataset also contains an estimate of maximal and minimal total carbon biomass based on maximal and minimal reported colony sizes (and thus maximal and minimal mucus), we do not visualize these results here. Uncertainties in the mucus contribution to total biomass due to these uncertainties in colony size range from hundreds to thousands of percent, and total carbon biomass estimates are far from certain at this point in time.

\section{Discussion}

We have estimated the carbon biomass of the haptophyte Phaeocystis from microscopic determinations of cell abundances. This approach is associated with several uncertainties.

First, since the data included in this database are sparse, we may have biases that we cannot account for. Whether the biomass estimates truly represent global averages is unclear. Free-living cells of Phaeocystis are often ignored in experimental studies, while colonies are counted, despite the fact 
(a)

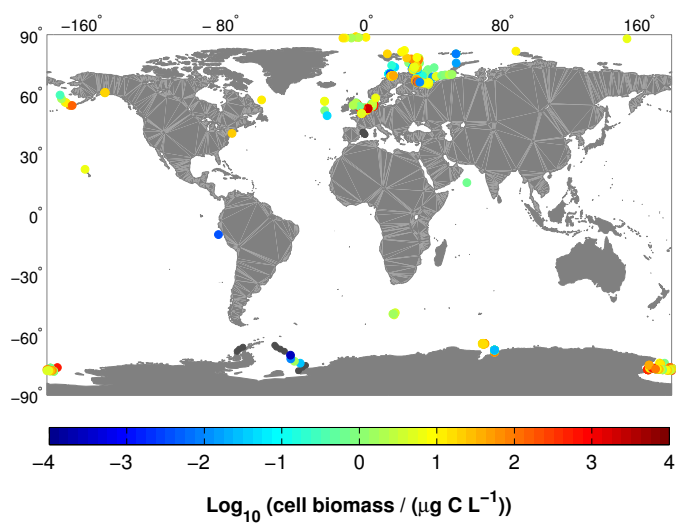

(b)

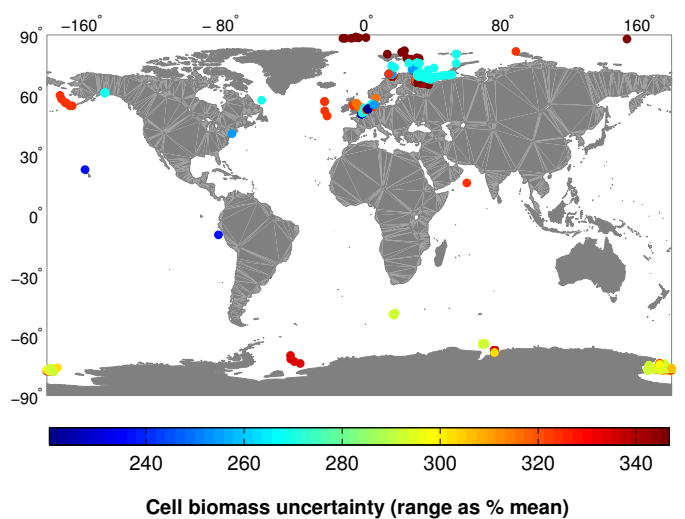

Figure 5. (a) Surface mean log-normalized Phaeocystis cell biomass concentrations in units of carbon $\left(\mu \mathrm{g} \mathrm{Cl}^{-1}\right)$ and (b) range of uncertainty in cell biomass in $\%$ of the mean, due to uncertainty in cell size. Black dots represent zero biomass values. Data has been log-transformed for a better visualization of the wide range of concentrations.

that there is always a background concentration of Phaeocystis cells when this genus is present in colonial form. Furthermore, even though Phaeocystis is ubiquitous (Schoemann et al., 2005), our data show a poor spatial resolution and data coverage outside the high-latitude coastal regions. Our biomass estimates for the coastal seas may not be representative of open ocean concentrations. Some areas such as the Pacific Ocean are clearly under-represented and we were not able to acquire any Phaeocystis measurements from the Northwest and West Pacific. Furthermore, there is a gap in our observations in the Arctic waters north of Siberia, and north of North America and in Greenland waters, despite published reports of high biomass off Greenland (Smith Jr., 1993). Our data is also seasonally biased in the Southern Hemisphere, with $58 \%$ of the data acquired during the summer months. In addition, we note that Phaeocystis is only accurately counted at times when it is expected to form large blooms, when there is a strong likelihood that its abundance is high and when scientists are specifically looking for this group. Hence, low background concentrations of singlecelled Phaeocystis will often be overlooked. Since the single- celled life stages of Phaeocystis lack a clear morphological distinction, this gap in our current knowledge is unlikely to be resolved using microscopic methods, but will require genetic identification methods.

Second, there are methodological issues with the determination of abundance data that will influence our biomass calculations. Several data contributors do not report the life stage cells were in at the time of sampling, most likely due to the disruption of colony structure during cell fixation. This fact results in difficulties in distinguishing single and colonial cells. Hence, in order to obtain a lower limit on Phaeocystis cell biomass, we chose to assume undefined cells to be in the form of flagellates, which will bias the resulting biomass calculations. The ratio of free-living to colonial cells is highly variable, but a significant background concentration of free-living cells is present even during bloom conditions. Our assumption that all unspecified cells are flagellates is therefore likely to lead to an underestimation of Phaeocystis cell biomass.

Furthermore, non-blooming species such as $P$. cordata, $P$. jahnii or $P$. scrobiculata are not recorded explicitly in our abundance data, but may constitute a non-negligible fraction of total global Phaeocystis biomass in some oceanic regions.

Third, there are large uncertainties associated with the conversion of cell abundances to biomass. Cell measurements were only provided for very few datasets; for the majority of the database, biovolumes were calculated using mean published cell dimensions. Cell size is highly variable for all Phaeocystis species (Schoemann et al., 2005) and using a constant biovolume estimate for each species will underestimate the spatial and temporal variability that occurs in Phaeocystis biomass. Due to the differences in the reported size range, our estimates of cell carbon content are different from some previously reported figures. For example, our estimates of cell carbon content for P. globosa (Table 2; flagellates: $13 \mathrm{pg} \mathrm{C}$ cell $^{-1}$; colonial cells: $29 \mathrm{pg} \mathrm{C}$ cell $\left.^{-1}\right)$ are higher than estimates by Rousseau et al. (1990; flagellates: $11 \mathrm{pg} \mathrm{C}$ cell $^{-1}$; colonial cells: $14 \mathrm{pg} \mathrm{C}$ cell $^{-1}$ ), and our estimates for $P$. antarctica (Table 2; flagellates: $9 \mathrm{pg} \mathrm{C}$ cell $^{-1}$; colonial cells: $\left.21 \mathrm{pg} \mathrm{C} \mathrm{cell}^{-1}\right)$ are higher than those reported by Mathot (2000; flagellates: $3 \mathrm{pg} \mathrm{C}$ cell $^{-1}$; colonial cells: $14 \mathrm{pg} \mathrm{Cell}^{-1}$ ) due to these differences in the reported mean cell diameters that were used to calculate the carbon estimates. Furthermore, literature values for the carbon conversion factor are only given for prymnesiophytes in general, but we lack information on the individual species of Phaeocystis, which may have a species-dependent, spatially and temporally varying cell carbon content.

Last, there is a large uncertainty associated with the addition of mucus carbon biomass due to the lack of data on cell forms, colony size and the amount of mucus per colonial cell. Greater use of preservation methods that maintain colony structure, along with routine colony size measurements, would allow for more reliable estimates of colonial mucus carbon. Further data on Phaeocystis colony sizes are 
(a)

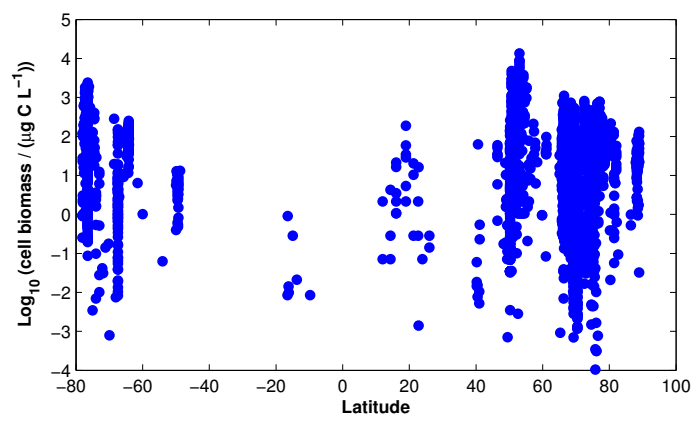

(b)

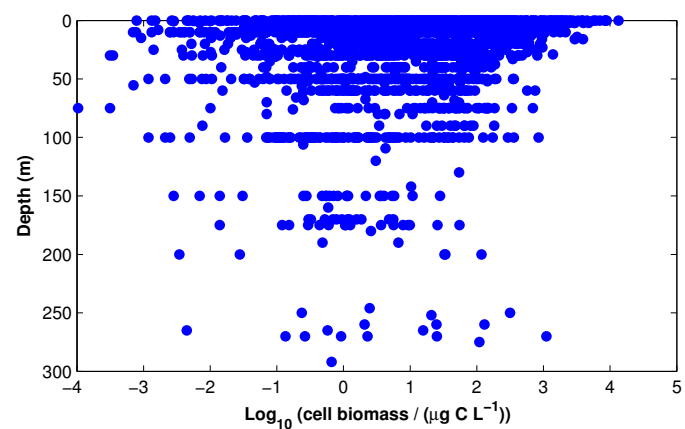

Figure 6. Distribution of non-zero log-normalized Phaeocystis cell biomass $\left(\mu \mathrm{gl}^{-1}\right)$ (a) as a function of latitude and (b) as a function of depth.

clearly needed if mucus carbon is to be included in global biomass estimates and model validation. Moreover, there are uncertainties related to the structure of the mucilaginous carbon surrounding colonies. For example, an alternative method for estimating the total carbon biomass of P. globosa has been suggested by Van Rijssel et al. (1997) based on the observed hollow structure of the colonies. Van Rijssel et al. (1997) compute total biomass per cell based on a linear relationship between colony surface area and carbon content. A comparison of the estimated mean total carbon per P. globosa cell leads to significant differences. For our standard colonies of $200 \mu \mathrm{m}$ diameter, we find total P. globosa carbon per cell to be $33.6 \mathrm{pg} \mathrm{C}$ cell $^{-1}$ following Rousseau et al. (1990, Table 2); we compute an amount of $202.5 \mathrm{pg} \mathrm{C}$ cell $^{-1}$ using Van Rijssel et al. (1997). The Rousseau relationship results in $9.6 \mathrm{ng} \mathrm{C}$ colony $^{-1}$, whereas the Van Rijssel relationship would lead to $58 \mathrm{ng} \mathrm{C}$ colony $^{-1}$ for this species. Prior to the publication of Verity et al. (2007), the contribution of mucus carbon to total carbon per cell for $P$. pouchetii was done using the Rousseau et al. (1990) and Mathot et al. (2000) or the Van Rijssel et al. (1997) formulations (Reigstad and Wassmann, 2007). Using these relationships, Reigstad and Wassmann (2007) find a much lower contribution of mucus $(10 \%)$ to total carbon per cell than what we find using Verity et al. (2007, 96.9\%). Earlier estimates of P. pouchetii mucus carbon may thus not be compatible with our estimations. Clearly, future studies are needed to address this uncertainty in colony structure and mucus distribution, and the corresponding volume to biomass conversion factors.

\section{Conclusions}

This is the first attempt at creating a global Phaeocystis biomass database. At present, however, we are still far from being able to give a global estimate of Phaeocystis biomass concentration. Data are limited by lack of spatial and temporal resolution, and at most sampling sites we lack a seasonal cycle that would be necessary to determine reasonable estimates for annual mean biomass concentration. Annual and monthly mean biomasses are of particular interest for the
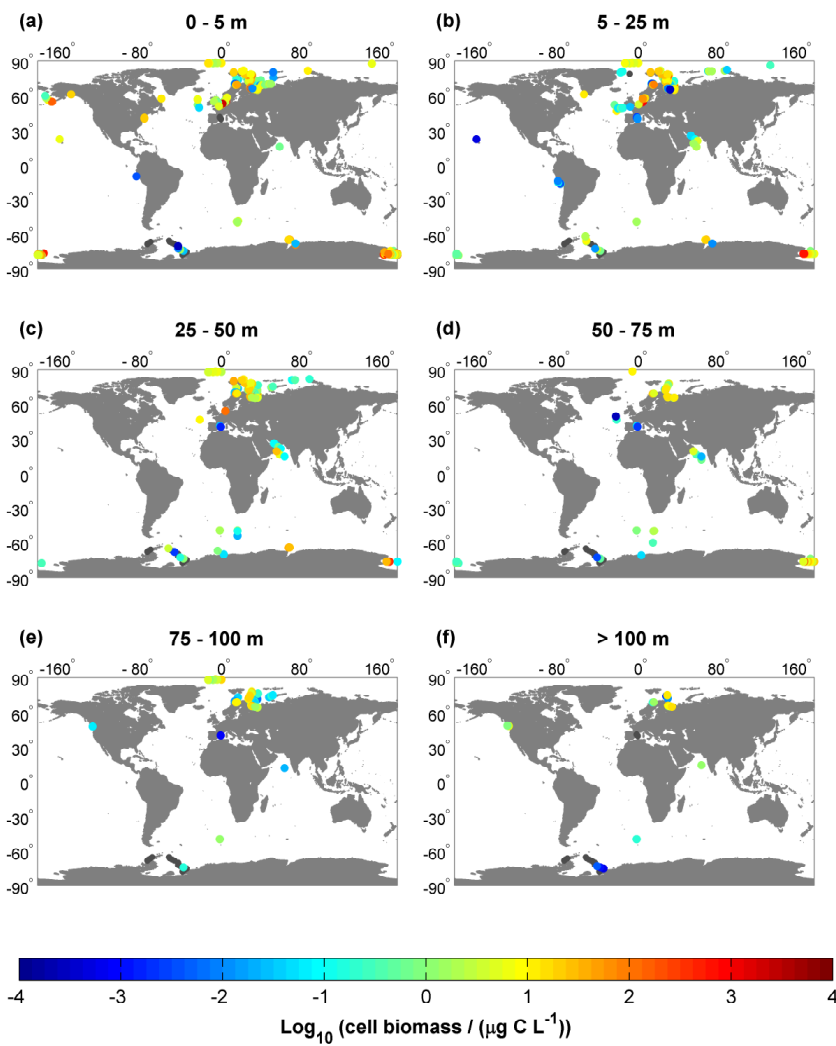

Figure 7. Log-normalized Phaeocystis cell biomass in units of carbon $\left(\mu \mathrm{g} \mathrm{Cl}^{-1}\right)$ at different depths (a) surface measurements $(0-5 \mathrm{~m})$ (b) measurements between 5-25 m (c) 25-50 m (d) 50-75 m (e) 75$100 \mathrm{~m}$ and (f) $>100 \mathrm{~m}$ depth. Black dots represent zero biomass values.

modelling community, but these will only be meaningful if further microscopic data can be added to the database. Targeted explorations of marine ecosystems with the aim to determine phytoplankton biomass would be desirable, but such endeavours tend to be expensive and laborious. A marine census of species biomass would shed light on the relative importance of key marine plankton groups and their respective importance for global biogeochemical cycling. 


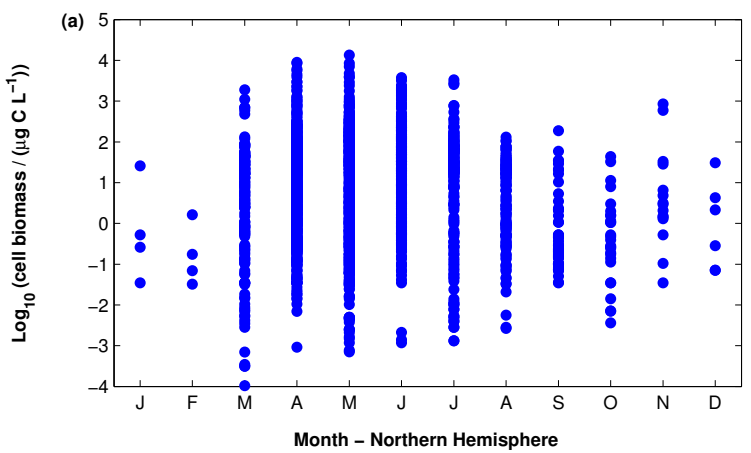

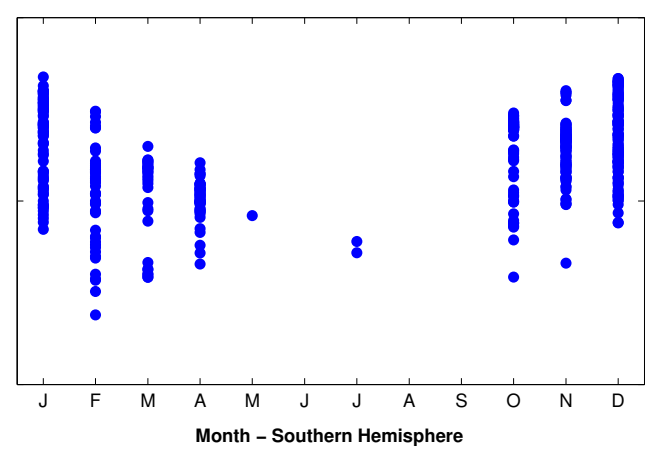

Figure 8. Seasonal distribution of log-normalized non-zero Phaeocystis cell biomass data for (a) the Northern and (b) the Southern Hemispheres.

(a)

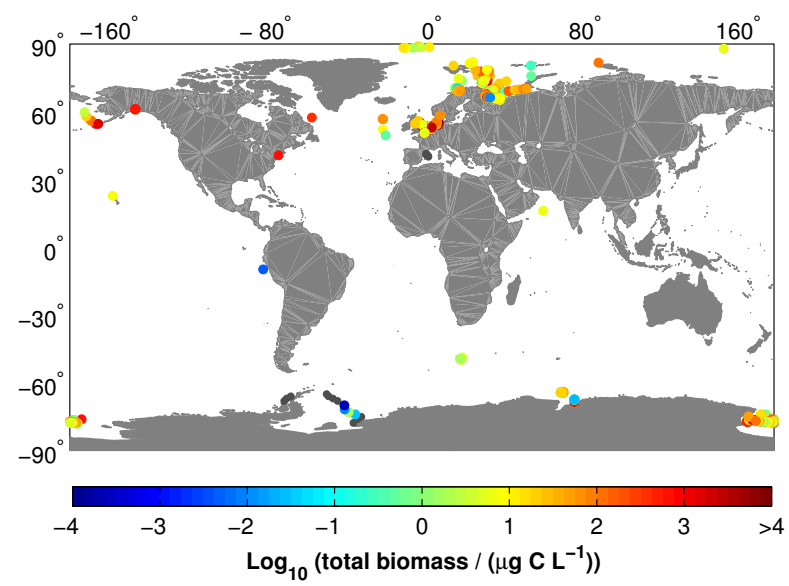

(b)

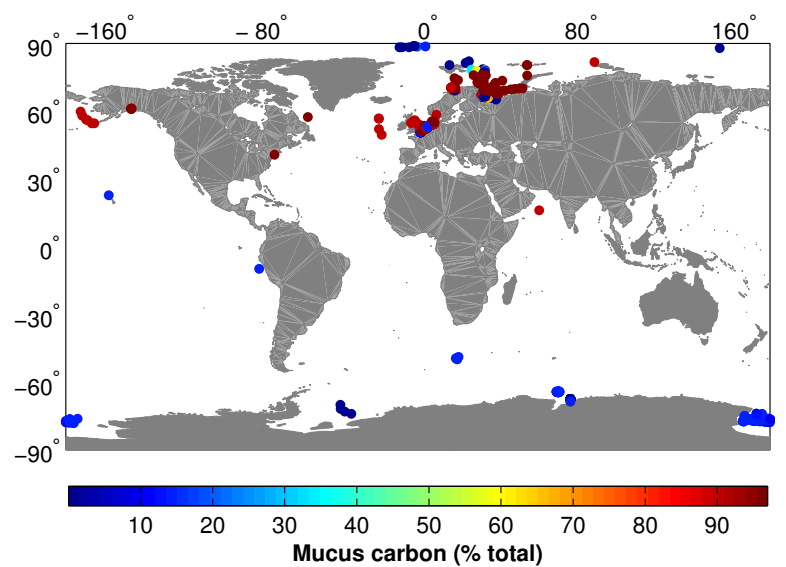

Figure 9. Estimates of (a) log-normalized total mean Phaeocystis biomass including colonial mucus for the surface layer $(0-5 \mathrm{~m})$ and (b) fraction of total mean surface biomass composed of mucus carbon. Zero values are not represented. The difference between the ratios of total carbon to cell carbon for the three species leads to a larger contribution by the Northern Hemisphere species to total Phaeocystis biomass.

\section{Appendix A}

\section{A1 Data table}

A full data table containing all biomass data points can be downloaded from the data archive PANGAEA, doi:10.1594/PANGAEA.779101. The data file contains longitude, latitude, depth, sampling time, abundance counts and biomass concentrations, as well as the full data references.

\section{A2 Gridded netCDF biomass product}

Monthly mean biomass data has been gridded onto a $360 \times$ $180^{\circ}$ grid, with a vertical resolution of 33 depth levels (equivalent to World Ocean Atlas depths) and a temporal resolution of 12 months (climatological monthly means). Data has been converted to netCDF format for easy use in model evaluation exercises. The netCDF file can be downloaded from PANGAEA, doi:10.1594/PANGAEA.779101. This file contains total and non-zero abundances, cell biomasses and total biomass estimates. For all fields, the means, medians and standard deviations resulting from multiple observations in each of the $1^{\circ}$ pixels are given. The ranges in cell and total biomasses due to uncertainties in cell size and life form are not included as variables in the netCDF product, but are given as ranges (minimum cell biomass, maximum cell biomass; minimum total biomass, maximum total biomass) in the data table.

Acknowledgements. We thank P. Assmy, G. C. Cadée, D. A. Caron, G. R. DiTullio, B. Hansen, I. R. Jenkinson, I. Joint, S.-H. Kang, B. Karlson, D. J. Lonsdale, S. Mathot, R. Riegman, M. W. Silver, W. O. Smith, P. Tett, P. Tréguer, R. Uncles, F. C. Van Duyl, E. L. Venrick, T. Weisse, G. V. Wolfe, and P. Wassmann for the permission to use and redistribute Phaeocystis data, and the BODC, JGOFS, OBIS OCB, PANGAEA and WOD databases for providing and archiving data. We also thank E. Buitenhuis for producing the gridded netCDF product, S. Doney for fruitful discussions on quality control, and S. Pésant for archiving the 
data. M. V. acknowledges funding from ETH Zürich. C. O'B.'s contribution to the research leading to these results has received funding from the European Community's Seventh Framework Programme (FP7 2007-2013) under grant agreement no [238366].

Edited by: S. Pesant

\section{References}

Aumont, O. and Bopp, L.: Globalizing results from ocean in situ fertilization studies, Global Biogeochem. Cy., 20, GB2017, doi:10.1029/2005GB002591, 2006.

Arrigo, K. R., Robinson, D. L., Worthen, R. B., Dunbar, R. B., DiTullio, G., R., VanWoert, M., and Lizotte, M. P.: Phytoplankton community structure and the drawdown of nutrients and $\mathrm{CO}_{2}$ in the Southern Ocean, Science, 283, 365-367, doi:10.1126/science.283.5400.365, 1999.

Assmy, P.: Phytoplankton abundance measured on water bottle samples at station PS65/587-1, Alfred Wegener Institute for Polar and Marine Research, Bremerhaven, doi:10.1594/PANGAEA.603400, 2007.

Baumann, M. E. M., Lancelot, C., Brandini, F. P., Sakshaug, E., and John, D. M.: The taxonomic identity of the cosmopolitan prymnesiophyte Phaeocystis: a morphological and ecophysiological approach, J. Marine Syst., 5, 5-22, 1994.

Beaugrand, G. and Reid, P. C.: Long-term changes in phytoplankton, zooplankton and salmon related to climate, Glob. Change Biol., 9, 801-817, 2003.

Boyer, T. P., Antonov, J. I., Baranova, O. K., Garcia, H. E., Johnson, D. R., Locarnini, R. A., Mishonov, A. V., O’Brien, T. D., Seidov, D., Smolyar, I. V., and Zweng, M. M.: World Ocean Database 2009, edited by: Levitus, S., NOAA Atlas NESDIS 66, US Government Printing Office, Washington, D.C., 216 pp., DVDs, 2009.

Buitenhuis E. T., Vogt, M., Moriarty, R., Bednarsek, N., Doney, S. C., Leblanc, K., Le Quéré, C., Luo, Y., O’Brien, C., O'Brien, T., Peloquin, J. M., and Schiebel, R.: MAREDAT: Towards a World Ocean Atlas of MARine Ecosystem DATa, Earth Syst. Sci. Data Discuss., in preparation, 2012.

Brown, S. L., Landry, M. R., Yang, E. J., Rii, Y. M., and Bidigare, R. R.: Diatoms in the desert: Plankton community response to a mesoscal eddy in the subtropical North Pacific, Deep-Sea Res. Pt. II, 55, 1321-1333, 2008.

Cadée, G. C.: Phaeocystis colonies wintering in the water column?, Neth. J. Sea Res., 28, 227-230, 1991.

Cadée, G. C. and Hegeman, J.: Seasonal and annual variation in Phaeocystis pouchetii (Haptophyceae) in the westernmost inlet of the Wadden Sea during the 1973 to 1985 period, Neth. J. Sea Res., 20, 29-36, 1986.

Cadée, G. C. and Hegeman, J.: Persisting high levels of primary production at declining phosphate concentrations in the Dutch coastal area (Marsdiep), Neth. J. Sea Res., 31, 147-152, 1993.

Chavez, F. P., Ryan, J., Lluch-Cota, S. E., and Niquen, M.: From anchovies to sardines and back: Multidecadal change in the Pacific Ocean, Science, 299, 217-221, 2003.

Chen, Y. Q., Wang, N., Zhang, P., Zhou, H., and Qu, L. H.: Molecular evidence identifies bloom-forming Phaeocystis (Prymnesiophyta) from coastal waters of southeast China as Phaeocystis globosa, Biochem. Syst. Ecol., 30, 15-22, 2002.
DiTullio, G. R., Grebmeier, J. M., Arrigo, K. R., Lizotte, M. P., Robinson, D. H., Leventer, A., Barry, J. P., VanWoert, M. L., and Dunbar, R. B.: Rapid and early export of Phaeocystis antarctica blooms in the Ross Sea, Antarctica, Nature, 404, 595-598, 2000.

Eilertsen, H. C., Taasen, J. P., and Weslawski, J. M.: Phytoplankton studies in the fjords of West Spitzbergen: physical environment and production in spring and summer, J. Plankton Res., 11, 1245-1260, 1989.

Estrada, M.: Phytoplankton assemblages across a new Mediterranean front: changes from winter mixing to spring stratification, Oecologia Aquatica, 10, 157-185, 1991.

Estrada, M. and Delgado, M.: Summer phytoplankton distributions in the Weddell Sea, Polar Biol., 10, 441-449, 1990.

Fransz, H. G., Gonzalez, S. R., Cadée, G. C., and Hansen, F. C.: Long-term change of Temora longicornis (copepoda, Calanoida) abundance in a Dutch tidal inlet (Marsdiep) in relation to eutrophication, Neth. J. Sea Res., 30, 23-32, 1992.

Glover, D. M., Jenkins, W. J., and Doney, S. C: Modeling Methods for Marine Science, Cambridge University Press, Cambridge, UK, ISBN: 978-0-521-86783-2, 2011.

Guiselin, N., Courcot, L., Artigar, L. F., Le Jéloux, A., and Brylinski, J.-M.: An optimized protocol to prepare Phaeocystis globosa morphotypes for scanning electron microscopy observation, J. Microbiol. Meth., 77, 119-123, 2009.

Hansen, B., Berggreen, U. C., Tande, K. S., and Eilertsen, H. C.: Post-bloom grazing by Calanus glacialis, C. finmarchicus and $C$. hyperboreus in the region of the Polar Front, Barents Sea, Mar. Biol., 104, 5-14, 1990.

Hashioka, T. and Yamanaka, Y.: Ecosystem change in the western North Pacific associated with global warming using 3DNEMURO, Ecol. Model., 202, 95-104, 2007.

Hatun, H., Payne, M. R., Beaugrand, G., Reid, P. C., Sando, A. B., Drange, H., Hansen, B., Jacobsen, J. A., and Bloch, D.: Large bio-geographical shifts in the north-eastern Atlantic Ocean: From the subpolar gyre, via plankton, to blue whiting and pilot whales, Prog. Oceanogr., 803, 149-162, 2009.

Hillebrand, H., Dürselen, C. D., Kirschtel, D., Pollingher, D., and Zohary, T.: Biovolume calculation for pelagic and benthic microalgae, J. Phycol., 35, 403-424, 1999.

Jenkinson, I. R. and Biddanda, B. A.: Bulk-phase viscoelastic properties of seawater: relationship with plankton components, J. Plankton Res., 17, 2251-2274, 1995.

Kang, S.-H. and Fryxell, G. A.: Phytoplankton in the Weddell Sea, Antarctica: Composition, abundance and distribution in watercolumn assemblages of the marginal ice-edge zone during austral autumn, Mar. Biol., 116, 335-348, 1993.

Karentz, D. and Spero, H. J.: Response of a natural Phaeocystis population to ambient fluctuations of UVB radiation caused by Antarctic ozone depletion, J. Plankton Res., 17, 1771-1789, doi:10.1093/plankt/17.9.1771, 1995.

Karlson, B., Edler, L., Granéli, W., Sahlsten, E., and Kuylenstierna, M.: Subsurface chlorophyll maxima in the Skagerrak-processes and plankton community structure, J. Sea Res., 35, 139-158, 1996.

Karlson, B., Cusack, C., and Bresnan, E. (Eds.): Microscopic and molecular methods for quantitative phytoplankton analysis, Paris, UNESCO, IOC Manuals and Guides, no. 55, 110 pp., 2010. 
Kennington, K., Allen, J. R., Wither, A., Shammon, T. M., and Hartnoll, R. G.: Phytoplankton and nutrient dynamics in the northeast Irish Sea, Hydrobiologia, 393, 57-67, 1999.

Koeman, R. P. T.: Analyses van fytoplankton en microzooplankton van het Friese Front 1999, Rapportage van onderzoek in opdracht van het Rijksinstituut voor Kust en Zee (RIKZ), Haren, The Netherlands, 1999 (in Dutch).

Le Quéré, C., Harrison, S. P., Prentice, I. C., Buitenhuis, E. T., Aumont, O., Bopp, L., Claustre, H., Da Cunha, L. C., Geider, R., Giraud, X., Klaas, C., Kohfeld, K. E., Legendre, L., Manizza, M., Platt, T., Rivkin, R. B., Sathyendranath, S., Uitz, J., Watson, A. J., and Wolf-Gladrow, D.: Ecosystem dynamics based on plankton functional types for global ocean biogeochemistry models, Glob. Change Biol., 11, 2016-2040, doi:10.1111/j.13652486.2005.1004.x, 2005.

Luchetta, A., Lipizer, M., and Socal, G.: Temporal evolution of primary production in the central Barents Sea, J. Marine Syst., 27, 177-193, 2000.

Mathot, S., Smith Jr., W. O., Carlson, C. A., Garrison, D. L., Gowing, M. M., and Vickers, C. L.: Carbon partitioning within Phaeocystis antarctica (Prymnesiophyceae) colonies in the Ross Sea, Antarctica, J. Phycol., 36, 1049-1056, 2000.

Medlin, L. and Zingone, A.: A taxonomic review of the genus Phaeocystis, Biogeochemistry, 83, 3-18, doi:10.1007/s10533007-9087-1, 2007.

Menden-Deuer, S. and Lessard, E. J.: Carbon to volume relationships for dinoflagellates, diatoms, and other protist plankton, Limnol. Oceanogr., 45, 569-579, 2000.

Moore, J. K. and Doney, S. C., Iron availability limits the ocean nitrogen inventory stabilizing feedbacks between marine denitrification and nitrogen fixation, Global Biogeochem. Cy., 21, GB2001, doi:10.1029/2006GB002762, 2007.

Moore, C. M., Hickman, A. E., Poulton, A. J., Seevaye, S., and Lucas, M. I.: Iron-light interactions during the Crozet Natural Iron Bloom Export Experiment (CROZEX): Part II - Taxonomic responses and elemental stoichiometry, Deep-Sea Res. Pt. II, 54, 2066-2084, doi:10.1016/j.dsr2.2007.06.015, 2007.

Palmisano, A. C., SooHoo, J. B., SooHoo, S. L., Kottmeier, S. T., Craft, L. L., and Sullivan, C. W.: Photoadaptation in Phaeocystis pouchetii advected beneath annual sea ice in McMurdo Sound, Antarctica, J. Plankton Res., 8, 891-906, 1986.

Peperzak, L. and Gäbler-Schwarz, S.: Current knowledge of the life cycles of Phaeocystis globosa and Phaeocystis antarctica (Prymnesiophyceae), J. Phycol., 48, 514-517, doi:10.1111/j.15298817.2012.01136.x, 2012.

Peperzak, L., Colijn, F., Gieskes, W.W.C. and Peeters, J.C.H.: Development of the diatom-Phaeocystis spring bloom in the Dutch coastal zone of the North Sea: the silicon depletion versus the daily irradiance threshold hypothesis. J. Plankton Res., 20(3), 517-537, doi:10.1093/plankt/20.3.517, 1998.

Peperzak, L., Colijn, F., and Peeters, J. C. H.: Observations of flagellates in colonies of Phaeocystis globosa (Prymnesiophyceae); a hypothesis for their position in the life cycle, J. Plankton Res., 22, 2191-2203, 2000.

Pieters, H., Kluytmans, J. H., Zandee, D. I., and Cadée, G. C.: Tissue composition and reproduction of Mytilus edulis in relation to food availability, Neth. J. Sea Res., 14, 349-361, 1980.

Reid, P. C., Johns, D. G., Edwards, M., Starr, M., Poulin, M., and Snoeijs, P.: A biological consequence of reducing Arctic ice cover: arrival of the Pacific diatom Neodenticula seminae in the North Atlantic for the first time in 800,000 years, Glob. Change Biol., 13, 1910-1921, doi:10.1111/j.1365-2486.2007.01413.x, 2007.

Reigstad, M. and Wassmann, P.: Does Phaeocystis spp. contribute significantly to vertical export of organic carbon?, Biogeochemistry, 83, 217-234, doi:10.1007/s10533-007-9093-3, 2007.

Riebesell, U., Reigstad, M., Wassmann, P., Noji, T., and Passow, U.: On the trophic fate of Phaeocystis pouchetii (haricot): VI. Significance of Phaeocystis-derived mucus for vertical flux, Neth. J. Sea Res., 33, 193-203, 1995.

Riegman, R., Rowe, A., Noordeloos, A. A., and Cadee, G. C.: Evidence for eutrophication induced Phaeocystis sp. blooms in the Marsdiep area (The Netherlands), in: Toxic Phytoplankton Blooms in the Sea, edited by: Smayda, T. J. and Shimizu, Y., Elsevier, 799-805, 1993.

Robinson, C., Archer, S. D., and le. B. Williams, P. J.: Microbial dynamics in coastal waters of East Antarctica: plankton production and respiration. Mar. Ecol.-Prog. Ser., 180, 23-36, 1999.

Rousseau, V., Mathot, S., and Lancelot, C.: Calculating carbon biomass of Phaeocystis sp. from microscopic observations, Mar. Biol., 107, 305-314, 1990.

Rousseau, V., Chrétiennot-Dinet, M.-J., Jacobsen, A., Verity, P., and Whipple, S.: The life cycle of Phaeocystis: state of knowledge and presumptive role in ecology, Biogeochemistry, 83, 29-47, doi:10.1007/s10533-007-9085-3, 2007.

Schoemann, V.: Effects of phytoplankton blooms on the cycling of manganese and iron in coastal waters, Limnol. Oceanogr., 43, 1427-1441, 1998.

Schoemann, V., Becquefort, S., Stefels, J., Rousseau, V., and Lancelot, C.: Phaeocystis blooms in the global ocean and their controlling mechanisms: A review, J. Sea Res., 53, 43-66, doi:10.1016/j.seares.2004.01.008, 2005.

Scott, F. J., Davidson, A. T., and Marchant, H. J.: Seasonal variation in plankton, submicrometre particles and size-fractionated dissolved organic carbon in Antarctic coastal waters, Polar Biol., 23, 635-643, 2000.

Seuront, L., Lacheze, C., Doubell, M. J., Seymour, J. R., Van Dongen-Vogels, V., Newton, K., Alderkamp, A. C., and Mitchell, J. G.: The influence of Phaeocystis globosa on microscale spatial patterns of chlorophyll a and bulk-phase seawater viscosity, Biogeochemistry, 83, 173-188, 2007.

Sherr, E. B. and Sherr, B. F.: Preservation and storage of samples for enumeration of heterotrophic protists, in: Handbook of Methods in Aquatic Microbial Ecology, edited by: Kemp, P. F., Sherr, B. F., Sherr, E. B., and Cole, J. J., Lewis Publishers, Boca Raton, 207-212, 1993.

Shields, A. R. and Smith, W. O.: Size-fractionated photosynthesis/irradiance relationships during Phaeocystis antarcticadominated blooms in the Ross Sea, Antarctica, J. Plankton Res., 31, 701-712, doi:10.1093/plankt/fbp022, 2009.

Smith, R. C., Przelin, B. B., Baker, K. S., Bidigare, R. R., Boucher, N. P., Coley, T., Karentz, D., MacIntyre, S., Matlick, H. A., Menzies, D., Ondrusek, M., Wan, Z., and Waters, K. J.: Ozone depletion: ultraviolet radiation and phytoplankton biology in Antarctic waters, Science, 255, 952-959, 1992.

Smith Jr., W.: Nitrogen uptake and new production in the Greenland Sea: The spring Phaeocystis bloom, J. Geophys. Res., 98, 46814688, 1993. 
Tréguer, P., Lindner, L., Leynaert, A., Panouse, M., and Jacques, G.: Production of biogenic silica in the Weddell-Scotia Seas measured with 32Si, Limnol. Oceanogr., 36, 1217-1227, 1991.

Van Duyl, F. C., Gieskes, W. W. C., Kop, A. J., and Lewis, W. E.: Biological control of short-term variations in the concentration of DMSP and DMS during a Phaeocystis spring bloom, J. Sea Res., 40, 221-231, 1998.

Van Rijssel, M., Hamm, C. E., and Gieskes, W. W. C.: Phaeocystis globosa (Prymnesiophyceae) colonies: hollow structures built with small amounts of polysaccharides, Eur. J. Phycol., 32, 185192, 1997.

Venrick, E. L.: Comparison of the phytoplankton species composition and structure in the climax area (1973-1985) with that of station ALOHA (1994), Limnol. Oceanogr., 42, 1643-1648, 1997.

Verity, P. G., Whipple, S. J., Nejstgaard, J. C., and Alderkamp, A. C.: Colony size, cell number, carbon and nitrogen contents of Phaeocystis pouchetii from western Norway, J. Plankton Res., 24, 359-367, 2007.

Vogt, M., Vallina, S. M., Buitenhuis, E. T., Bopp, L., and Le Quéré, C.: Simulating dimethylsulphide seasonality with the Dynamic Green Ocean Model PlankTOM5, J. Geophys. Res.-Oceans, 115, C06021, doi:10.1029/2009JC005529, 2010.

Wang, S. and Moore, J. K.: Incorporating Phaeocystis into a Southern Ocean ecosystem model, J. Geophys. Res., 116, C01019, doi:10.1029/2009JC005817, 2011.
Wassmann, P., Ratkova, T., and Reigstad, M.: The contribution of single and colonial cells of Phaeocystis pouchetii to spring and summer blooms in the north-eastern North Atlantic, Harmful Algae, 4, 823-840, 2005.

Weaver, S. S.: Ceratium in Fire Island Inlet, Long Island, New York (1971-1977), Limnol. Oceanogr., 24, 553-558, 1979.

Weber, T. S. and Deutsch, C.: Ocean nutrient ratios governed by plankton biogeography, Nature, 467, 550-554, doi:10.1038/nature09403, 2010.

Weisse, T., Grimm, N., Hickel, W., and Martens, P.: Dynamics of Phaeocystis pouchetii blooms in the Wadden Sea of Sylt (German Bight, North Sea), Estuar. Coast. Shelf Sci., 23, 171-182, 1986.

Widdicombe, C. E., Eloire, D., Harbour, D., Harris, R. P., and Somerfield, P. J.: Long term phytoplankton community dynamics in the Western English Channel, J. Plankton Res., 32, 643-656, 2010.

Wolfe, G. V., Levasseur, M., Cantin, G., and Michaud, S.: DMSP and DMS dynamics and microzooplankton grazing in the Labrador Sea: application of the dilution technique, Deep-Sea Res. Pt. I 47, 2243-2264, 2000. 